\title{
Présentation du numéro 42
}

\section{(2) OpenEdition}

1 Journals

Édition électronique

URL : https://journals.openedition.org/ries/1143

DOI : 10.4000/ries. 1143

ISSN : 2261-4265

Éditeur

France Education international

\section{Édition imprimée}

Date de publication : 1 septembre 2006

ISSN : 1254-4590

Référence électronique

"Présentation du numéro 42 », Revue internationale d'éducation de Sèvres [En ligne], 42 I septembre 2006, mis en ligne le 15 novembre 2011, consulté le 08 juillet 2021. URL : http://

journals.openedition.org/ries/1143; DOI : https://doi.org/10.4000/ries.1143

Ce document a été généré automatiquement le 8 juillet 2021.

() Tous droits réservés 


\section{Présentation du numéro 42}

1 La Revue internationale d'éducation de Sèvres éditée par le Centre international d'études pédagogiques consacre sa livraison de septembre 2006 à l'éducation artistique dans sept pays: Canada (Québec), Slovaquie, Japon, Australie, Angleterre, Belgique, France.

2 Garante de la transmission d'une culture et des pratiques qui l'accompagnent, héritière d'une tradition éducative souvent séculaire, l'éducation artistique est aujourd'hui mise en question par la mondialisation des échanges culturels et l'offre croissante d'interfaces de consommation et de création.

3 Tout en abolissant les frontières, enfants et adolescents inventent de nouvelles pratiques qui bousculent les repères artistiques et la façon de se les approprier.

Comment les politiques d'éducation artistique tirent-elles les conséquences de ces évolutions majeures?

Cet accès individuel et aisé à des œuvres de plus en plus diversifiées assure-t-il pour autant une éducation artistique pour tous?

Comment les politiques éducatives favorisent-elles l'accès du plus grand nombre à la culture artistique?

4 Les articles réunis par ce dossier, présentant et analysant la situation de l'éducation artistique dans sept contextes géographiquement et culturellement éloignés, permettent de mesurer la façon dont sont pensées les missions, les responsabilités et les stratégies de l'Ecole dans ce domaine.

5 Ce dossier de la Revue internationale d'éducation de Sèvres présente les stratégies déployées et les réponses apportées dans les six pays observés. 